\title{
A New Alternative to Museum Activities in Teaching Social Studies Course: “360-Degree Videos as a Virtual Museum"*
}

\begin{abstract}
Ali KIRKSEKİZ**
Onur İŞBULAN ${ }^{* * *}$

Selçuk Sırrı TERCAN ${ }^{* * * * *}$
\end{abstract}

\begin{abstract}
In this study, social studies teachers working in Serdivan district of Sakarya province were asked about their opinions on virtual reality, 360-degree videos and virtual museum, it was ensured that they made a museum visit via the "360-Degree Video Based Virtual Museum Application (360DVVMA)", and their views were examined in depth. A semi-structured interview form was used as the data collection tool in the research. 2 descriptive question items to be asked to the teachers before implementation and 5 questions items to be asked after the implementation were prepared about the virtual museum application. The question items were submitted to expert opinions, required changes were made to the items, and the semi-structured interview form was finalized. According to the findings of the study, most of 9 social studies teachers knew about the concept of virtual museum and benefited from virtual museum applications in their classes, and 4 of them had never heard the concept of virtual reality before. 5 teachers stated that they had only heard of the concept but had no experience before and 360DVVMA could be used in the classes. Furthermore, the teachers emphasized that if 360DVVMA was used in instructional processes, it would provide equal opportunities in education for students who do not have the opportunity to go to museums as well as offering a great contribution to their academic development.
\end{abstract}

Keywords: Social studies teaching, virtual museum, virtual reality

\footnotetext{
* Ethics committee permission for this study was obtained from the Ethics Committee of the Rectorate of Sakarya University of Applied Sciences with the number of E.3658 dated 29/04/2020.

** Orcid ID: https://orcid.org/0000-0002-7873-3402, Lecturer, Sakarya University of Applied Sciences,

Turkey, alik@subu.edu.tr

*** Orcid ID: https://orcid.org/0000-0001-5326-071X, Assist. Prof. Dr., Sakarya University, Turkey, oisbulan@sakarya.edu.tr

**** Orcid ID: https://orcid.org/0000-0001-9338-9403, Lecturer, Sakarya University, Turkey, akiper@sakarya.edu.tr

***** Orcid ID: https://orcid.org/0000-0002-1541-2951, Lecturer, Sakarya University, Turkey, sstercan@sakarya.edu.tr

****** Orcid ID: https://orcid.org/0000-0001-9458-7831, Prof. Dr., Sakarya University, Turkey, mkiyici@sakarya.edu.tr
} 


\section{INTRODUCTION}

It is of importance to bring individuals, who have knowledge as well as the skill to access the required information depending on the problematic situation and produce solutions to their own problematic situations, to the society in the face of today's rapidly advancing information. One of the most important steps to this end is the effective use of technologies that cause such rapid development of information in instructional processes. If these new technologies are used in learning-teaching processes, it is possible to eliminate or minimize the disadvantages of the learners who have certain limitations. Hence, it is also very important for the professionals who work in the teaching-learning process to increase their skills and experiences in this area by integrating relevant technologies to the instructional processes.

"Virtual reality" is one of the most efficiently used technologies in learning and teaching processes since its introduction (Huang, Rauch \& Liaw, 2010; Jang, Vitale, Jyung \& Black, 2017). Virtual reality can be described as a technology which allows individuals to get the feeling that the environment or objects they are in interaction with are real with through the deception of their sensory organs with technology. Furthermore, virtual reality is defined as environments that offer high reality (Kuliga, Thrash, Dalton \& Hölscher, 2015), where realtime computer graphics, various sensors and body tracking devices are used (Emmelkamp, Krjin, Hulsbosch, De Vires, Schuemie \& Van der Mast, 2002) and users and computer systems interact with techniques and technologies (Silva, do Espirito Santo, Marins, de Siqueira, Mol \& de Abreu Mol, 2015). While it is possible to materialize abstract concepts, ensure that individuals can interact with phenomena/events which are hard or impossible to be visited, seen and experienced, individual learning is supported to pave the way for learning by discovering through virtual reality (Cheng \& Wang, 2011; Howard, 2017; Lee, Wong \& Fung, 2010).

It is particularly important to support the students with real-life experiences in the courses such as social studies, science where off-school learning environments and activities performed in these environments are included in the curricula. Trips to places such as museums, zoos and science centers are organized to provide these real-life experiences. However, there may be limitations of planning these trips and carrying out them in accordance with instructional objectives. There are significant limitations to the performance of instructional activities via museum trips, which are of great importance in social studies course. Although there are many environments prepared with virtual reality for virtual museums for the last years (Giangreco \& others, 2019; Schweibenz, 2019; Takeuchi, Hayashi \& Hirayama, 2019) no virtual museum application prepared especially with 360 degree videos is encountered in the literature. It is possible to exemplify them as financial difficulties, difficulties in obtaining the necessary permits, limitations about the visits to places outside the province or remote places. On the other hand, there are recommendations in the social studies curriculum about the use of virtual museums in instructional processes to eliminate such limitations (MEB, 2018). With virtual museum applications of museums, teachers can display virtual museum visits on smartboards or reflect them on the board via projection devices to make virtual museum visits with their students in the classroom setting. It is possible to perform these instructional activities in which students watch the reflected images also via virtual reality technologies. Due to very high costs of the technologies (glasses, 
wearable technologies, simulators, etc.) required to either produce virtual reality contents or interact with these contents, they do not have common usage at schools. Yet, it has been made possible to make virtual museum visits with virtual reality in classrooms as the difficulty of producing content has been eliminated and virtual reality glasses can now be procured at low costs with the widespread use of 360-degree video technology.

\section{Virtual Museum and 360-Degree Videos}

Virtual Museum can be defined as museums that are formed with digital objects, have no physical integrity but are of similar characteristics, that do not need any physical space to offer access across the world and where people can access all kinds of audio, image and video record about these objects (Andrews, 1998, Çolak, 2006, Güleç, 2003, McKenzie, 1997). Virtual museums mostly come across as websites where information about the collections exhibited in the museum and exhibited/not exhibited sections of the museum or artworks is shared with visitors. In some virtual museums, it is possible to visit museums via a simulation of the museum or with 360-degree panoramic photos to enable individuals who cannot visit the museum to understand the physical properties of both the museum and the exhibited works.

One can also create virtual museums with virtual reality solutions that help provide the sense of reality in a digital environment. However, such contents are not commonly used in museums as producing virtual reality contents requires a serious digital design process and experts and have very high costs. In recent years, 360-degree video recording technologies have emerged as an alternative to simulations preferred to create virtual reality content. 360degree videos are videos created by combining images, which are obtained by 360-degree viewing of the current environment via multiple cameras with specific techniques. To achieve a virtual reality experience with 360-degree videos, virtual reality glasses and a video player that divides the screen into two in compliance with the glasses are required.

The basic logic of 360-degree videos rapidly growing popular nowadays is to create more impacts than single-view videos and to give individuals the experience of reality within a single image with a few minor movements. Cameras that can record high-resolution video are needed to produce a good 360-degree video for capturing the reality to be presented to the people. A camera that can record 360 degrees of video through a single lens does not exist yet. 360-degree video production can be done with a single camera with at least two lenses that see all angles as well as the combination of two or more cameras with a single lens and similar hardware features in general. 360-degree video can be produced by performing simultaneous shooting with cameras that are combined in a special structure so as to see the whole 360 degree angle and then processing the videos obtained from each camera by processing in computer environment.

Thus, it is possible to perform museum visits through the experience closest to the sense of reality when the 360 -degree museum video content is viewed with virtual reality glasses. In this way, people who do not have the opportunity can visit museums, and it also contributes to equal opportunities in education through the instructional activities performed with the 360-degree video contents that are prepared in accordance with the objectives of the course.

From this point of view, the use of 360 degree virtual museum applications in the teaching of Social Studies course, where teaching activities with the museum are of great importance, will 
eliminate many limitations on this issue. When the literature is examined, it is seen that the museum and teaching activities in the teaching of social studies lessons cannot be carried out adequately due to the high legal responsibility of the school administration and teachers, the reluctance of the administrators and teachers, the too many curriculum subjects, and insufficient course hours (Akkuş \& Meydan, 2013; Ata, 2002) Baykan, 2007; Gökmen, 2004; Malkoç, 2014; Öner, 2015). The use of virtual museum applications created with 360-degree videos, which is a newly developing technology, in classroom can eliminate these limitations. Therefore, the purpose of this study is to examine how much the teachers who will apply this technology know about this technology.

\section{Problem of the Research}

The following sentences constitute the problem of this research.

1. What are the opinions of teachers about virtual museums?

2. What are the opinions of teachers about virtual reality?

3. Do teachers want to use a virtual reality application created with 360-degree videos in their class?

\section{METHOD}

The research was conducted with the phenomenological research method which is one of the qualitative research methods. In phenomenological research, data sources are individuals or groups that experience the phenomenon that the research focuses on and that can express or reflect this phenomenon. Phenomenology research may not produce generalizable results. However, these studies can provide examples, explanations and experiences that provide results that will help to better recognize and understand a phenomenon (Ylldırım \& Şimşek, 2013, p.72). In this study, the in-service social studies teachers were asked about their opinions on virtual reality, 360-degree videos and the virtual museum, and then the 360degree video virtual museum recorded at the Mevlana Museum in Konya was visited with virtual reality glasses, and the post-implementation opinions of the social studies teachers were examined in depth. For this reason, the phenomenological research method was preferred to check what are teachers' views on virtual reality phenomenon, what they think about virtual reality and whether there is any change in this phenomenon of teachers after the application of 360-degree virtual museum. The videos used in this process were selected from the videos suitable for viewing 360 degrees on Youtube. The subjects related to the videos are prepared based on the acquisitions in the Social Studies course. Ethics committee permission for this study was obtained from the Ethics Committee of the Rectorate of Sakarya University of Applied Sciences with the number of E.3658 dated 29/04/2020.

\section{Study Group}

The study group consisted of 9 social studies teachers in the Serdivan district of Sakarya province. The teachers selected for the study group were contacted with and included in the study upon their approval. All of the teachers in the study group were social studies teachers working in different middle schools in Serdivan district. The main reason for working with 
social studies teachers is that there are subjects related to museums in the social studies course curriculum and that social studies teachers are obliged to offer more experience and real-life skills to students in relation to museums. The reason for choosing Serdivan district is that the social studies teachers in the district are easily accessible.

\section{Instrument}

A semi-structured interview form was used as the data collection tool in the research. Preparing a form for the interview is very important to ensure that the interview is valid and reliable and can be performed properly. When preparing the interview form, it is important to write down easy-to-understand questions, prepare focused questions and open-ended questions, avoid directing during the interview and utilize different kinds of questions (Yıldırım \& Şimşek, 2013).

The questions in the semi-structured interview form were divided into pre- and post360DVVMA questions. 2 descriptive pre-360DVVMA question items to be asked to the teachers such as about concept of virtual reality and whether they had experienced virtual museum before and 5 post-360DVVMA question items to be asked about the virtual museum application were prepared. The question items were submitted to 2 experts working in the Department of Social Studies Education, 2 experts working in the Department of Computer Education and Instructional Technologies and one expert in working the Department of Assessment and Evaluation for review. Required changes were made to the items, and the semi-structured interview form was finalized after the expert opinions had been received.

\section{Data Collection}

Research data were collected in interviews. Interview is defined as an interaction-based process of communication which is performed for a predetermined and serious objective and receives answers through the question-asking method. The concept of the process mentioned in the definition refers to the continuous and dynamic structure of mutual communication. This dynamic structure requires a connection based on an interaction. Interview's feature of being planned and purposeful distinguishes the interview technique from being a conversation and makes it a planned effort to collect data. The question-answer method used in the interview can be described as the way of establishing a relationship and accessing data when collecting data (Yıldırım \& Şimşek, 2013).

Prior to the interviews, required permissions were obtained from Sakarya Provincial Directorate of National Education to collect data. Before the interviews, the social studies teachers were contacted by the researchers for appointment and were visited for 3 weeks at their schools. The first three of the items in the semi-structured interview form had been asked to the teachers before the application was shown to them and the opinions of the teachers were recorded with a voice recorder. The 360DVVMA developed by the researchers was applied to the teachers, and the experience they had with the application was concluded with the last 5 items in the semi-structured interview form. These items include the experience gained from the practice, the attitude towards the virtual museums, and the recommendations. Each interview lasted an average of 15 minutes, and all data were recorded by a voice recorder during the interviews. 


\section{Data Analysis}

The data obtained from the semi-structured interview form were interpreted in a descriptive analysis. The purpose with this type of analysis is to present the findings to the reader in an organized and interpreted way (Yıldırım \& Şimşek, 2013).

An inductive approach was adopted in this research. All the audio recordings obtained during the research were transcribed, all data were examined line by line, and the category lists were created according to the questions in the form. After the category lists had been set, common aspects were determined, and thematic coding for these common aspects was carried out. It was ensured during thematic coding that the data constituted a whole for internal validity and the themes were different while forming a whole for external validity. The data were evaluated separately by two researchers for the reliability of the study. For calculating the reliability of the study, the reliability formula proposed by Miles and Huberman (1994) was used:

$$
\text { Reliability = Agreement } / \text { (Agreement + Disagreement) }
$$

The coefficient for each theme was found to be greater than 0.70 for the themes. Microsoft Excel 2013 program was used for the analysis of the qualitative data.

\section{FINDINGS}

The data obtained in the research were evaluated within the scope of qualitative findings, and the codes, categories and themes determined in accordance with the semi-structured interview form were analyzed and reported by Microsoft Excel 2013 software.

\section{Findings Related to the Research Question "What do you think when you say 'Virtual Museum'? Have you used it before in your classes?"}

In this section, the opinions of the teachers about the concept of virtual museum and their opinions about its use in the courses are interpreted below.

Table 1

Teacher opinions about the concept of Virtual Museum and its usage in courses

\begin{tabular}{lll}
\hline Opinions & Knows the concept of Virtual Museum & $\mathrm{f}$ \\
\hline Awareness & Does not know the concept of Virtual Museum & 8 \\
\hline $\begin{array}{l}\text { Whether teachers use } \\
\text { it }\end{array}$ & Have used the Virtual Museum in the courses & 1 \\
\hline Disadvantages & Have not used the Virtual Museum in the courses & 2 \\
\hline & $\begin{array}{l}\text { Internet connection problem in schools } \\
\text { Insufficient physical infrastructure in schools }\end{array}$ & 4 \\
\hline & Not enough weekly class hours & 3 \\
\hline & Lack of teachers' practical competencies & 2 \\
\hline
\end{tabular}




\begin{tabular}{ll}
\hline Advantages & 3 \\
Attracts students' attention & 3 \\
$\begin{array}{l}\text { Provides equal opportunity to students who do not have } \\
\text { the means to visit museums }\end{array}$ & 3 \\
$\begin{array}{l}\text { Supports student learning } \\
\text { Students have the ability to use technology effectively }\end{array}$ & 2 \\
Expands students' perspectives & 1
\end{tabular}

According to the Social Studies teacher opinions on the concept of the virtual museum and its use in the courses in Table 1, 8 of the teachers knew about the concept of virtual museum and 7 of them were utilizing the virtual museum applications in their courses. Regarding the findings obtained from the answers about the usage of virtual museum applications in the courses, the teachers reported that the limitations to the usage of virtual museum applications they encountered in the classroom were primarily the Internet connection problem in schools and lack of physical infrastructure to carry out these applications. They also added that they did not have enough time to perform such activities in their courses due to few weekly class hours of the social studies course and the high number of attainments they need to provide in the curriculum. Another limitation reported by the teachers is that teachers did not have sufficient skills for the use of applications such as virtual museum. As the advantages that would be primarily offered by the use of virtual museum applications in the course, the teachers stated that it help students materialize the abstract concepts with which they have the greatest difficulty in the social studies course, it enables them to focus on the course further and provides equal opportunity to students who do not somehow have the means to visit these museums. They also stated that it supports students' learning, attracts their attention even further because of their high skills of using technology and contributes to the expansion of students' perspectives of the course.

\section{Findings Related to the Research Question "Have you ever heard of the Concept of Virtual Reality?"}

In this section, the quantitative findings of the research question whether the teachers' had heard about the concept of virtual reality are interpreted below.

Table 2.

Teacher opinions about the concept of Virtual Reality

\begin{tabular}{lll}
\hline Opinions & & $\mathrm{f}$ \\
\hline Awareness & Does not know the concept of Virtual Reality & 4 \\
& Partially knows the concept of Virtual Reality & 3 \\
& Knows the concept of Virtual Reality & 2
\end{tabular}


Concerning the Social Studies teacher opinions on the concept of Virtual Reality in Table 2, 4 of the teachers had never heard of the concept before and 3 of them had only heard the concept before but had no experience. Only 2 of the social studies teachers stated that they had previously heard the concept of virtual reality and had the opportunity to experience it. The probing question whether they were using the virtual reality applications in their classes was asked to the teachers who had heard the concept of virtual reality and had the opportunity to experience it before, and all of them answered that they were not utilizing the virtual reality applications in their classes.

At this stage of the interview, the concept of Virtual Reality was explained to the teachers, and an exemplary application was opened with virtual reality glasses to enable them to have a virtual reality experience. The 360-degree video recorded in the Mevlana Museum in Konya province was shown to the teachers with virtual reality glasses as the exemplary virtual museum application. In this section, the quantitative findings related to teachers' attitudes towards the use of 360DVVMA in their courses are interpreted below.

Findings Related to the Research Question "Would you consider using the 360-Degree Video Based Virtual Museum Application in your courses?

In this section, the quantitative findings related to teachers' attitudes towards the use of 360DVVMA in their courses are interpreted below.

Table 3

Teacher attitudes towards the use of 360DVVMA in courses

\begin{tabular}{lll}
\hline Opinions & & $\mathrm{f}$ \\
\hline Attitude & I would use in my classes & 9 \\
& I would not use in my classes & 4 \\
\hline Advantages & Contributes to student learning & 4 \\
& Allows students to learn by experience & 3 \\
& Activates students in the instructional process & 3 \\
& Provides equal opportunities for students & 2 \\
& Improves students' perspectives & 2 \\
& Makes the course fun & 2 \\
& Materializes abstract concepts & 1 \\
& It is about different learning styles & 1
\end{tabular}


In Table 3, it is seen that all of the social studies teachers reported their opinions that the 360DVVMA which they had experienced could be used in the courses. When asked about the reasons for using 360DVVMA in the courses, 4 of the teachers stated that it would help students learn by experience and contribute to their learning with statements similar to the following:

"I would consider it. It would be very nice, too. We would instruct the subjects to the kids in a better way. We would make them experience it. Nicer results would be achieved. We would enjoy it very much, too. I am sure the kids would not know how the course started and they would enjoy and learn about their history. (T6)"

3 of the teachers stated that it would activate students in the instructional process and particularly provide equal opportunity to students who do not have the means to visit museums as in the following statement:

"Sure, why would I not consider? I think it might be good on kids. It is not an application that every child can use at home. When he/she sees it at the school, it can be more active for him/her. (T9)"

2 of the teachers stated that it would contribute to the development of students' perspectives, make the courses fun for students and be effective in materializing abstract concepts in the instruction of social studies course as in the following exemplary statement:

"Of course I would consider it. Because a university student has the chance to wonder and make a visit but students of the 5th, 6th, 7th, 8th grades do not have the means; so, they can learn about everything around the world very easily and have an idea in this way. The world of the child will change. He/she will have seen the truth. The child will at least have an experience through a computer system. When I would tell the child about Mevlana, he/she would not remember him, but he/she would have the chance to walk around in it, something would surely remain in his/her mind. (T8)"

In addition, 1 of the teachers said that it addressed different learning styles of students and would attract their attention. 2 of the teachers stated that they did not have enough time to use such activities in the instructional process because the social studies course has few weekly class hours.

\section{Findings Related to the Research Question "What types of features do you expect in this application so as to be used in instructional processes?"}

In this section, the qualitative findings in regard to the features that 360DVVMA should have so as to be used in instructional processes are interpreted below. 
Table 4

Teacher opinions on the features that 360DVVMA should have so as to be used in instructional processes

\begin{tabular}{llc}
\hline Opinions & $\mathrm{f}$ \\
\hline Features & Narration & 6 \\
& Background Music & 5 \\
& Narrator & 3 \\
Teaching Activity & 2 \\
Guidance & 1 \\
Frequency of use & 1 \\
\hline
\end{tabular}

Regarding the social studies teacher opinions about the features that 360DVVMA should have so as to be used in the instructional processes, 6 of the teachers stated that there should be narration so that the virtually visited museum can serve to the instructional objectives. The teachers stated that there should be a background music to keep students' motivations alive in their interaction with the application as follows:

"There should be definitely audio narration because it is not enough for children just to see at certain points. They only see it but also need to know about its uses or what it is used for or where it comes from; they need to make connection. You need to establish a bond between what you see and the brain. This should be supported by teachers. There should be a few options, for instance. One of the children can tell, maybe because each child has different knowledge. (T9)"

5 of the teachers shared the opinion that there should be a background music to keep students' motivations alive in their interaction with the application. The following sentences may be given as examples of this opinion:

"There must be sound. Not only visual but also an impressive music. Janissary music when visiting the Topkapı Palace would be nicer. There will be the visuals, surely. There must be plenty of them. (T7)"

Furthermore, 3 of the teachers stated that having a narrator (teacher or student/peer) in virtual museum images would contribute to more positive results while 2 of them stated that virtual museum applications to be used in instructional processes should be planned within the framework of a teaching activity. One of the teachers said that there should be guidance in the narrations to attract the attention of the students to the important places of the virtual museum and virtual museum applications should not be used much frequently in the instructional processes. 
Findings Related to the Research Question "What types of advantages could using this application in instructional processes offer in your opinion?"

In this section, the opinions of the teachers about the advantages of using the 360DVVMA in instructional are interpreted below.

Table 5

Advantages to be offered by the use of 360DVVMA in instructional processes

\begin{tabular}{lll}
\hline Opinions & f \\
\hline Advantages & Contributes to student learning & 7 \\
& Allows students to learn by experience & 4 \\
& Activates students in the instructional process & 4 \\
& Provides equal opportunities for students & 4 \\
Attracts students' attention & 2 \\
\hline
\end{tabular}

As for the the social studies teacher opinions on the advantages of using the 360DVSMU in instructional processes in Table 5, 7 of the teachers stated that it would contribute to student learning.

"It would ensure retentive learning. Not everything about children is just mathematics or teaching. This is a culture, I think. For me, it is very important to see different places, question your past and learn something from your past in education. I think it would be important for them, too. (T5)"

4 of the teachers stated that it would contribute to students' learning by experience, activate students in instructional processes and provide equal opportunities to students.

"It will enable students to learn by experience and have the chance to see places, where they cannot access and go, in 3 dimensions. It is something close to every kind of intelligence. The fact that student can see it. It would be of use. (T1)"

2 of the teachers shared the opinion that it would attract the attention of the students in instructional processes.

Findings Related to the Research Question "What types of disadvantages could using this application in instructional processes have in your opinion?"

In this section, the opinions of the teachers about the disadvantages of using the 360DVVMA in instructional are interpreted below. 
Table 6

Disadvantages to be presented by the use of 360DVVMA in instructional processes

\begin{tabular}{ll}
\hline Opinions & $\mathrm{f}$ \\
\hline Disadvantages & $\begin{array}{l}\text { Need for instruments (phone - glasses) required for the } \\
\text { application }\end{array}$ \\
$\begin{array}{l}\text { May lead to negativity in classroom management } \\
\text { Supports students' technology addiction } \\
\text { Voids the desire to go to the museum } \\
\text { Affects students' health adversely }\end{array}$ & 3 \\
\hline
\end{tabular}

Regarding the social studies teacher opinions on the disadvantages of using 360DVVMA in instructional processes in Table 6, 4 of the teachers stated that not all students having virtual reality glasses and smartphones to be required for using the application in the classroom would be the biggest disadvantage with statements similar to the following:

"Of course, these equipment are hard to reach. Their supply may be a bit of a nuisance. (T4)"

3 of the teachers reported that teachers could experience problems in classroom management during the implementation and it would support their technological addiction.

"They would have problem with attention. We can use it for a short while, we can give it for 3 or 5 minutes, in parts, during the course. Otherwise, my students... It could attract 2 - 3 students' attention but others may get bored. It is not possible if you cannot keep others busy for 40 minutes. Therefore, it can be given for a short time. The subject contents can be compacted. Education is not just about using it. We can only use it as a material. (T8)"

2 of the teachers stated that it could void the desire of students with this experience to go to museum and one of them reported that it could affect students' health adversely.

\section{Findings Related to the Research Question "What are your recommendations on the use of 360-Degree Video Based Virtual Museum Applications?"}

In this section, the recommendations of the teachers about the disadvantages of using the 360DVVMA in instructional are interpreted below. 
Table 7

Recommendations on the use of 360DVVMA in instructional processes

\begin{tabular}{llc}
\hline Opinions & f \\
\hline Recommendations & Content suitable for attainments & 4 \\
& Museums for ancient times & 2 \\
& Physical environments should be created & 2 \\
& Should encourage to visit the actual museum & 1 \\
Teachers should be trained & 1 \\
\hline
\end{tabular}

According to the social studies teacher recommendations on the use of 360DVVMAs in instructional in Table 7, 4 of the teachers shared that the preparation of the contents to be prepared in accordance with the attainments in the curriculum would provide better results. 2 of the teachers stated that it would be useful to conduct studies for museums for ancient times which could be effective in teaching old-era concepts that are found abstract by students and it would be beneficial to establish classrooms/laboratories where virtual museums created with virtual reality can be experienced and there is equipment to be required for them. 1 of the teachers reported that the virtual museum applications to be prepared should encourage the students to go to the real museum and the teachers should be trained so that these applications can be used effectively in instructional processes.

\section{RESULTS, DISCUSSIONS AND SUGGESTIONS}

Studies conducted in the domain of virtual reality which has regained its popularity with new technologies and tools nowadays indicate that virtual reality can be easily used in instructional processes with contents to be developed in this domain. The in-service teachers were consulted for opinion to put forth the features that instructional materials to be created should have in the context of virtual reality and the matters to be considered in regard to their usage in instructional processes. The research was carried out with volunteers from the social studies teachers still working in middle schools in the district of Serdivan, Sakarya province. Given the findings obtained in the interviews which were performed within the scope of the research;

Almost all of the social studies teachers used the virtual museum application in their classes through smartboards or projection devices and stated that they experienced its great contribution to the attitudes and academic achievements of the students. Moreover, they reported that they did not have the opportunity to use virtual museums due to the lack of physical infrastructure in schools and few weekly class hours of the social studies course. These findings are consistent with the results of the studies performed by Ata (2002), Malkoç (2014), and Öner (2015). Therefore, to eliminate the time problem of teachers due to the intensive curriculum, teaching activities prepared in accordance with the curriculum and 
which can be used together with 360DVVMA and presented in platforms such as Educational Informatics Network (EBA) will positively affect the use of such technologies by teachers. The use of instructional materials such as the virtual museum in teaching environments requires teachers to make a preliminary preparation as well as and to plan relevant learning activities. If these preparations are made, they may present a solution that could eliminate the problem of not having sufficient class hours described as a limitation. On the other hand, the inadequacy of physical infrastructure in schools is a limitation that avoids the use of instructional activities involving such technologies in instructional processes. However, it is possible that students perform instructional activities involving 360DVVMA with low-cost virtual reality glasses at home with at least 8 out of every 10 households having Internet connection, $97 \%$ of households having mobile phones and smartphone usage which has become more popular (Güler, Şahinkayası and Şahinkayası, 2017). In this way, it will be possible to incorporate instructional activities involving the virtual museum which cannot be performed due to the physical deficiencies in the schools into instructional processes.

It was understood that majority of the social studies teachers did not have a complete knowledge of the concept of virtual reality. This can be interpreted as an indication that teachers do not have sufficient knowledge about the use of current technologies in instructional processes. On the other hand, the teachers stated that using these applications in instructional processes would provide quite useful results after the concept of virtual reality had been explained to the teachers and they had been made experience 360DVVMA. All of the teachers stated that they could use such applications in their courses if they had sufficient means (physical infrastructure, content, technology experience). This finding coincides with the studies conducted by Monahan, McArdle \& Bertolotto (2008); Merchant, Goetz, Cifuentes, Keeney-Kennicutt \& Davis (2014), and Howard (2017). It is therefore possible to argue that providing in-service trainings in the use of new-generation instructional technologies specific to teachers' domain of teaching as well as applications to be introduced by Directorates of National Education and/or Ministry of National Education which will encourage teachers tending to use new-generation instructional technologies in their classes will have a positive impact on teacher attitudes and motivations regarding the use of such technologies in the classroom.

The teachers emphasized that if 360DVVMAs were used by teachers in instructional processes, it would provide equal opportunities in education for students who do not have the opportunity to go to museums as well as offering a great contribution to their academic development. This finding also coincides with the findings of studies on the use of virtual museums in the instructional process (Yıldırım \& Tahiroğlu, 2012; Ustaoğlu, 2012; Ermiş, 2010). The teachers also stated that they could face the problem of classroom management during the application and there should be adequate number of devices.

The social studies teachers reported certain features that need to be considered by developers when developing these applications so as to achieve successful and effective results in using 360DVVMAs in instructional processes. These features expressed by the teachers include that 360DVSMUs have not only images of the museum but also have a content parallel to the attainments in the curriculum, this content is narrated by a narrator, it would be better if the 
narrator was a teacher or a peer student and it would be good if various instructional activities were planned by teacher after the student had been made experience this application.

The research was carried out with social studies teachers. Therefore, it can be said that it is limited only to social studies teachers. The results of the research can be generalized with 360 degree videos that will be developed especially for not only virtual museums but for different areas. The virtual museums prepared by teachers with 360 degree videos can be examined through the permanence research whether their likes are instant or permanent. However, technical data can be obtained about virtual museums using different display technologies (different glasses, different lenses, videos in different resolutions).

\section{References}

Akkuş, A., \& Meydan, A. (2013). Sosyal bilgiler öğretiminde tarihi ve coğrafi mekân uygulamalarının değerlendirilmesi [Evaluation of historical and geographical place implementations in social sciences teaching]. Uluslararası Avrasya Sosyal Bilimler Dergisi [International Eurasian Journal of Social Sciences], 4(13), 14-30

Andrews, J. (1998). A new medium for old masters: the kress study collection virtual museum project. Art documentation. Journal of the Art Libraries Society of North America, 17(1), 1927.

Ata, B. (2002). Müzelerle ve tarihi mekanlarla tarih öğretimi: Tarih öğretmenlerinin "müze eğitimine" iliş̧in görüşleri (Unpublished doctoral dissertation). Gazi University, Ankara.

Baykan, Z. Ö. (2007). 2005 ve 2006 İlköğretim Programlarının Müze Eğitimi Açısından Değerlendirilmesi (Unpublished masters' thesis) Ankara University, Ankara.

Cheng, Y., \& Wang, S. H. (2011). Applying a 3D virtual learning environment to facilitate student's application ability-The case of marketing. Computers in Human Behavior, 27(1), 576-584.

Çolak, C. (2006). Sanal Müzeler [Virtual Museums]. Türkiye"de İnternet Konferansı Bildirileri, 2123 Aralık, TOBB Ekonomi ve Teknoloji Üniversitesi, 293-296.

da Silva, M. H., do Espírito Santo, A. C., Marins, E. R., de Siqueira, A. P. L., Mol, D. M., \& de Abreu Mol, A. C. (2015). Using virtual reality to support the physical security of nuclear facilities. Progress in Nuclear Energy, 78, 19-24.

Emmelkamp, P. M. G., Krijn, M., Hulsbosch, A. M., De Vries, S., Schuemie, M. J., \& Van der Mast, C. A. P. G. (2002). Virtual reality treatment versus exposure in vivo: a comparative evaluation in acrophobia. Behaviour research and therapy, 40(5), 509-516.

Ermiş, B. (2010). İlköğretim 6.Sinıf Öğrencilerinin Görsel Sanatlar Dersinde "Üç Boyutlu Sanal Müze Ziyareti” Etkinliğine İlişkin Görüşleri (Unpublished masters' thesis). Gazi University, Ankara.

Giangreco, I., Sauter, L., Parian, M. A., Gasser, R., Heller, S., Rossetto, L., \& Schuldt, H. (2019, March). VIRTUE: a virtual reality museum Experience. In Proceedings of the 24th International Conference on Intelligent User Interfaces: Companion (pp. 119-120).

Gökmen, C.O. (2004). İlköğretim I. Kademede Müzelerin Öğretim Ortamı Olarak Yeri (Unpublished masters' project) Ankara University, Ankara.

Güleç, S., \& Alkış, S. (2003). Sosyal bilgiler öğretiminde müze gezilerinin iletişimsel boyutu [Communicative dimension of museum visits in social studies teaching]. Uludağ Üniversitesi Eğitim Fakültesi Dergisi, 17(1), 63-78.

Güler, H., Şahinkayasi, Y., \& Şahinkayasi, H. (2017). İnternet ve mobil teknolojilerin yaygınlaşması: firsatlar ve sinırlılıklar [The Penetration of Internet and Mobile Information Technologies: Opportunities and Limitations]. Sosyal Bilimler Dergisi, 7(14), 186-207.

Howard, M. C. (2017). A meta-analysis and systematic literature review of virtual reality rehabilitation programs. Computers in Human Behavior, 70, 317-327. 
Huang, H. M., Rauch, U., \& Liaw, S. S. (2010). Investigating learners' attitudes toward virtual reality learning environments: Based on a constructivist approach. Computers \& Education, 55(3), 1171-1182.

Jang, S., Vitale, J. M., Jyung, R. W., \& Black, J. B. (2017). Direct manipulation is better than passive viewing for learning anatomy in a three-dimensional virtual reality environment. Computers \& Education, 106, 150-165.

Kuliga, S. F., Thrash, T., Dalton, R. C., \& Hölscher, C. (2015). Virtual reality as an empirical research tool-Exploring user experience in a real building and a corresponding virtual model. Computers, Environment and Urban Systems, 54, 363-375.

Lee, E. A. L., Wong, K. W., \& Fung, C. C. (2010). How does desktop virtual reality enhance learning outcomes? A structural equation modeling approach. Computers \& Education, 55(4), 14241442.

Malkoç, S. (2014). Sosyal bilgiler öğretiminde sınıf dışı okul ortamlarının kullanılma durumları (Unpublished masters' thesis). Anadolu University, Eskișehir.

McKenzie, J. (1997). Building a virtual museum community. In Museums and the Web. Conference (pp. 77-86).

MEB, (2018). Milli Eğitim Bakanlığı, Sosyal Bilgiler Dersi Öğretim Programı (İlkokul ve Ortaokul 4,5,6, ve 7. Sinıflar) [Ministry of National Education, Social Studies Curriculum (Primary and Secondary School 4,5,6 and 7th Grades)], Ankara.

Merchant, Z., Goetz, E. T., Cifuentes, L., Keeney-Kennicutt, W., \& Davis, T. J. (2014). Effectiveness of virtual reality-based instruction on students' learning outcomes in K-12 and higher education: A meta-analysis. Computers \& Education, 70, 29-40.

Miles, M., \& Huberman, A. (1994). Qualitative Data Analysis (2nd edition). Thousand Oaks, CA: Sage Publications.

Monahan, T., McArdle, G., \& Bertolotto, M. (2008). Virtual reality for collaborative e-learning. Computers \& Education, 50(4), 1339-1353.

Öner, G. (2015). Sosyal bilgiler öğretmenlerinin 'okul dışı tarih öğretimi'ne ilişkin görüşlerinin incelenmesi. Turkish History Education Journal, 4(1), 89-121.

Schweibenz, W. (2019). The virtual museum: an overview of its origins, concepts, and terminology. The Museum Review, 4(1), 1-28.

Takeuchi, K., Hayashi, M., \& Hirayama, M. J. (2019, March). Development of VR museum and a comparison with the screen-based virtual museum. In International Workshop on Advanced Image Technology (IWAIT) 2019 (Vol. 11049, p. 110491B). International Society for Optics and Photonics.

Yıldırım, A., \& Şimşek, H. (2013). Sosyal Bilimlerde Nitel Araștırma Yöntemleri [Qualitative research methods in the social sciences]. Ankara: Seçkin Yayıncllık.

Yildirim, T., \& TAHİROĞLU, M. (2012). Sanal ortamda gerçekleştirilen müze gezilerinin ilköğretim öğrencilerinin sosyal bilgiler dersine yönelik tutumlarina etkisi [The effects of virtual museum visits on elementary students' attitudes towards social studies courses]. Elektronik Sosyal Bilimler Dergisi, 11(39), 104-114.

Ustaoğlu, A. (2012). İlköğretim 7. Sınıf sosyal bilgiler dersi Türk tarihinde yolculuk ünitesinde sanal müzelerin kullanımının öğrenci başarısına etkisi (Unpublished masters' thesis). Gazi University, Ankara. 
Ethics committee permission for this study was obtained from the Ethics Committee of the Rectorate of Sakarya University of Applied Sciences with the number of E.3658 dated 29/04/2020. 